the British Electrical Power Convention. Lord Chandos, who delivered the Messel Medal address to the Society of Chemical Industry on May 6 (Chem. and Indust., 1037 ; August 13), did not in that address renew this plea; but, dealing with research and finance in industry, suggested that statements that research and development effort in Britain are too small are misleading. He put expenditure in Great Britain on research and development in 1959 at about $£ 450$ million, of which the Government financed one third of that carried out by private industry ; about 27 per cent of the total is in the hands of Government and nationalized industry and performed by them. Lord Chandos believes that more attention should be given to the wider implications of this huge research and development effort. Man's ability to create wealth is increasing much faster than is generally appreciated, and we must be prepared to take some risks to ensure that our means of exchange should increase in a planned and calculated way parallel with the new wealth.

\section{Arctic Institute of North America}

THE Arctic Institute is inviting applications from research scientists interested in arctic and subarctic North America and in Antarctica. The aims of the Institute's grant-in-aid programme, which last year numbered thirty-five awards ranging in value from 400 to 10,000 dollars, are to support the work of experienced field-scientists and to introduce other competent researchers to polar science. The Institute favours no particular scientific disciplines, but appraises proposals on their individual merit. Grants are usually made for a one-year period. Opportunities for field research in arctic Alaska and Canada have widened considerably since the International Geophysical Year. The Institute can now assist research workers in obtaining laboratory facilities and field-stations for many kinds of work. For example, the Office of Naval Research's Arctic Research Laboratory at Point Barrow, Alaska, offers laboratory facilities for work in oceanography, seaice, ecology, geology and soil science, and arctic climatology. The Institute is establishing this year two stations on Devon Island, N.W.T., for glaciological, marine biological and meteorological studies. Opportunities exist at stations on the Ellesmere Island Ice Shelf and Ice Island $T-3$ for work in glaciology, sea-ice, oceanography, and marine biology. The Institute maintains one small glacier station and is associated with another on the northern slope of Brooks Range in Alaska. The Arctic Institute also invites proposals for support of field-research in Antarctica. Applications must be submitted a full year in advance of an antarctic field-season. Further information about the programme and application forms can be obtained from the Arctic Institute of North America, 3485 University Street, Montreal 2, P.Q., or 1530 P Street N.W., Washington, D.C. Applications for grants for 1961 should be sent in before November 1,1960 .

\section{Boris Kidrich Institute of Nuclear Sciences}

VoLUme 10 (March 1960) of the Bulletin of the Boris Kidrich Institute of Nuclear Sciences at Vinca, near Belgrade, contains twenty-five articles and one laboratory note contributed by members of the physics, physical chemistry, applied mathematics, electronics and radiobiology laboratories of the Institute. Continuing their work on the development of three basic methods-coincidence, $4 \pi$ and solidangle methods - for the absolute measurement of beta activity, V. Urošević and co-workers describe techniques and methods developed for the primary standardization of gold-198. The results obtained agreed with measurements made at Harwell on four gold foils to within the limits of the estimated error (2-6 per cent). New apparatus described include a thorium fission chamber, a low-pressure expansion cloud-chamber, and a high-resolution binary and decade counting unit. Nine papers deal with radiobiological topics. The brief news report included in Volume 10 records that during 1959 more than sixty scientists from other research centres visited the Institute. Eight delegations, including representatives of the International Atomic Energy Agency, Poland, France, the U.S.S.R., Cambodia, United Arab Republics, and Ethiopia, were received. A joint meeting of Polish and Yugoslav physicists to discuss beta. and gamma-spectroscopy was held at the Institute during September, a symposium on analytical chemistry during October and a symposium on solid state physics and chemistry during December. The construction of an experimental reactor of $6 \cdot 5$ MW. (2 per cent enriched uranium and heavy water), delivered by the U.S.S.R. in accordance with an agreement between Yugoslavia and the U.S.S.R., was completed, and the reactor, which first became critical on October 28, began to operate officially on December 28.

\section{Geological Research in the Northern Highlands of Scotland}

THE past fifteen years have witnessed active development of geological research in the Northern Highlands, with many younger workers added to those of the pre-war period. The new (third) edition of the "Handbook of Regional Geology" on "Scotland : The Northern Highlands", by Dr. J. Phemister, lists more than 150 references additional to those in the original printing of the second edition in 1948 (H.M.S.O. 5s. net). The great majority of these concern detailed researches on the structure, metamorphic history and correlation of the Lewisian and Moine metamorphic rocks ; but in view of the active controversies centred on the interpretation of much of this work at the present time, it was not deemed profitable to attempt a complete summary and assessment of it in the present edition. The bulk of the 1948 text is reprinted without modification, additional paragraphs directing attention to more recent publications. By this means the Handbook will serve as a comprehensive and unbiased guide in this field of research until such time as the main controversies are resolved and we can welcome a definitive fourth edition.

\section{National Museum of Wales}

The Department of Zoology at the National Museum of Wales, Cardiff, has recently arranged an exhibit to illustrate the interchange of animal species between Wales and some of the Commonwealth countries. For centuries the Merchant Navy has played an important part in this, for animals of different types such as insects, small mammals and lizards as well as plants have been transferred to new parts of the world. Accidental or deliberate importation has led to a mingling of once characteristic types for any particular country. Thus, the British wintermoth is spreading in Canada, the North American 